\title{
Implementasi Model Discovery learning dalam Meningkatkan Prestasi Belajar Siswa Kelas IV Madrasah Ibtidaiah (MI) Al-Ma'arif Gendingan Kec. Kedungwaru Kab. Tulungagung
}

\section{Sigit Dwi Laksana}

Fakultas Agama Islam Unmuh Ponorogo Prodi PGMI

Email: sigitciovi@gmail.com

\begin{abstract}
ABSTRAK:
Proses belajar mengajar merupakan suatu proses yang mengandung serangkaian perbuatan guru dan siswa atas dasar hubungan timbal balik yang berlangsung dalam situasi edukatif untuk mencapai tujuan tertentu. Seorang guru sangat berperan sekali dalam dunia pendidikan salah satu tugas yang harus dilaksanakan oleh guru di sekolah ialah memberikan pelayanan kepada para siswa agar mereka menjadi siswa yang selaras dengan tujuan sekolah, salah satu bentuk pelayanannya yaitu dengan memberikan susana pembelajaran yang menyenangkan dalam bentuk model pembelajaran yang mampu membangkitkan gairah belajar siswa, utamanya dalam beberapa mata pelajaran yang dituntut untuk berfikir analisis, seperti PKn, melalui beberapa model pembelajaran yang tepat dapat menghasilkan kualitas pembelajaran yang baik, salah satunya yitu model discovery learning, dalam penelitian ini akan banyak membahas tentang efektifnya model pembelajaran discovery learning pada mata pelajaran PKn.
\end{abstract}

Kata kunci: Implementasi, Model Discovery Learning, Prestasi Belajar

\section{A. PENDAHULUAN}

Kita ketahui belajar mengajar adalah suatu kegiatan yang bernilai edukatif. Nilai edukatif mewarnai interaksi yang terjadi antara guru dengan peserta didik. Interaksi yang bernilai edukatif dikarenakan kegiatan belajar mengajar yang dilakukan diarahkan untuk mencapai tujuan tertentu yang telah dirumuskan sebelum pengajaran dilakukan. Guru dengan sadar merencanakan kegiatan pengajarannya (proses pembelajaran) secara sistematis dengan memanfaatkan segala sesuatunya guna kepentingan pengajaran karena proses pembelajaran merupakan bagian terpenting dari sebuah kegiatan pendidikan. Proses pembelajaran adalah suatu upaya untuk mencapai tujuan pendidikan. Tujuan pendidikan tidak akan dapat terlaksana tanpa adanya suatu proses pembelajaran yang ada di suatu lembaga pendidikan.

Dalam proses belajar anak-anak usia sekolah dasar mempunyai pemikiran yang bersifat konkrit, integratif, dan hierarkis. Konkrit dimaknai sebagai proses belajar harusnya beranjak dari hal-hal yang konkrit yakni yang dapat dilihat, didengar, dibaui, diraba, dan diutak-atik. Integratif dimaknai sebagai keadaan di mana anak memandang sesuatu yang dipelajari sebagai suatu keutuhan, mereka belum mampu memilah-milah konsep dari 
berbagai disiplin ilmu. Sementara hirarkis bermakna bahwa anak belajar berkembang secara bertahap mulai dari hal-hal yang sederhana ke hal-hal yang lebih kompleks.

Belajar seharusnya adalah suatu proses perubahan di dalam kepribadian yang berupa kecakapan, sikap, kebiasaan, dan kepandaian yang bersifat menetap dalam tingkah laku yang terjadi sebagai suatu hasil dari latihan atau pengalaman. Pembelajaran diartikan proses komunikasi dua arah, mengajar dilakukan oleh pihak guru sebagai pendidik, sedangkan belajar dilakukan oleh peserta didik atau murid (Syaiful Sagala, 2012: 61).

Dalam proses pembelajaran, keberhasilan belajar peserta didik dipengaruhi oleh faktor internal dan eksternal. Dimana salah satu faktor internal tersebut adalah kualitas belajar peserta didik itu sendiri. Selain faktor internal, faktor eksternal pun sangat mempengaruhi. Faktor eksternal yang sangat penting adalah guru, dimana guru harus berusaha untuk tercapainya tujuan pembelajaran di kelas. Sebagai seorang guru, kita harus mampu memilih dan mendesain model pembelajaran yang tepat bagi peserta didik. Model pembelajaran yang dipilih harus disesuaikan dengan tema dan kompetensi dasar yang harus dimiliki peserta didik. Di samping itu juga harus memperhatikan keadaan atau kondisi peserta didik, bahan pelajaran, serta sumber-sumber belajar yang ada agar penggunaan model pembelajaran tersebut dapat diterapkan secara efektif dan dapat menunjang keberhasilan belajar peserta didik.

Salah satunya model pembelajaran yang dapat digunakan yaitu model discovery learning. Penggunaan model discovery ini merupakan salah satu hal yang dapat menentukan keberhasilan proses pembelajaran seorang guru. Penggunaan model belajar yang sesuai dengan materi yang sedang dipelajari bertujuan agar peserta didik mampu menangkap pelajaran dengan mudah, menguasai konsep serta aktif dalam kegiatan belajar mengajar di kelas. Menurut E. Mulyasa penggunaan model yang tepat akan turut menentukan efektivitas dan efesiensi pembelajaran (E. Mulyasa, 2008: 107).

Untuk mencapai kondisi tersebut, diperlukan implementasi model pembelajaran yang dapat membuat peserta didik aktif dalam pembelajaran seperti aktif dalam mengeluarkan pendapat dan menemukan konsep sendiri. Misalnya untuk mata pelajaran yang memiliki karakteristik seperti mata pelajaran Pendidikan Kewarganegaraan, IPA, dan Matematika, maka pemilihan modelnya juga yang harus mengaktifkan peserta didik jika diimplementasikan dengan model ceramah juga kurang efektif dan efisien, maka peimplementasian model discovery learning ini sangat cocok karena model pembelajaran ini prosedurnya mengarah peserta didik untuk memperoleh pengetahuan yang belum 
diketahuinya itu tidak melalui pemberitahuan, sebagian atau seluruhnya ditemukan sendiri. Dalam pembelajaran discovery learning, mulai dari strategi sampai dengan jalan dan hasil penemuan ditentukan oleh peserta didik sendiri. Kebiasaan ini akan di transfer dalam kehidupan bermasyarakat. Beranjak dari hal tersebut penulis merasa tergerak untuk mengadakan penelitian tersebut dengan menekankan pada beberapa poin permasalah yaitu bagaimana penerapan pendekatan kontekstual untuk meningkatkan prestasi belajar PKn siswa kelas IV MI Al-Ma'arif Gendingan Kedungwaru Tulungagung dan bagaimana peningkatan prestasi belajar PKn siswa kelas IV MI Al-Ma'arif Gendingan Kedungwaru Tulungagung melalui penerapan pendekatan kontekstual?

\section{B. LANDASAN TEORI}

\section{Model Discovery Learning}

\section{a. Pengertian}

Proses pembelajaran memiliki keterkaitan yang sangat erat dalam proses pendidikan dan tidak dapat dipisahkan. Pembelajaran merupakan kegiatan yang harus dilakukan oleh seorang pendidik, agar tercipta suasana/iklim belajar pada siswa, dibutuhkan satu model pembelajaran yang mendukung suasana anak dalam belajar.

Menurut Arends, model pembelajaran mengacu pada pendekatan yang akan digunakan, termasuk didalamnya tujuan-tujuan pembelajaran, tahap-tahap dalam kegiatan pembelajaran, lingkungan pembelajaran, dan pengelolaan kelas. Melalui model pembelajaran guru dapat membantu peserta didik mendapatkan informasi, ide, keterampilan, cara berfikir, dan mengekspresikan ide (Richard I Arends, 2008: 40). Model pembelajaran berfungsi pula sebagai pedoman bagi para perancang pembelajaran dan para guru dalam merencanakan aktivitas belajar mengajar.

Sedangkan discovery learning adalah teori belajar yang didefinisikan sebagai proses pembelajaran yang terjadi bila peserta didik tidak disajikan dengan pelajaran dalam bentuk finalnya tetapi peserta didik mengorganisasi sendiri pelajaran tersebut. Model pembelajaran ini menekankan pada ditemukannya konsep atau prinsip yang sebelumnya tidak diketahui. Guru berperan sebagai pembimbing dengan memberikan kesempatan kepada peserta didik untuk belajar secara aktif. Bahan ajar tidak disajikan dalam bentuk akhir tetapi peserta didik dituntut untuk melakukan serangkaian kegiatan mulai dari mengumpulkan informasi sampai dengan membuat kesimpulan dari materi yang disajikan. Menurut Syah dalam mengaplikasikan model discovery learning di 
kelas, ada beberapa langkah-langkah operasional baik dalam persiapan ataupun pelaksanaannya (M. Syah, 2004: 15).

Model ini juga memiliki sistem penilaian sebagai acuan evaluasi. Selain itu model discovery learning juga memiliki kelebihan tersendiri sehingga dapat diperhitungkan penggunaannya untuk mencapai tujuan pembelajaran. Namun selain kelebihan model ini tentu juga memiliki kelemahan. Jadi kelebihan dan kelemahan model discovery learning dapat dijadikan pertimbangan guru.

\section{Prestasi Belajar}

\section{a. Pengertian Hasil Belajar}

Kata prestasi belajar dapat dijelaskan dengan memahami dua kata yang membentuknya, yaitu "prestasi" dan "belajar". Prestasi juga bisa dikatakan sebagai hasil. Menurut Saifuddin Azwar "prestasi atau hasil yang telah dicapai oleh siswa dalam belajar" (Saifuddin Azwar, 2005: 13). Prestasi merujuk pada suatu perolehan akibat dilakukannya suatu aktivitas atau proses yang mengakibatkan berubahnya input secara fungsional (Purwanto, 2009: 44).

Sedangkan belajar adalah suatu kegiatan yang dilakukan dengan melibatkan dua unsur, yaitu jiwa dan raga (Syaiful Bahri Djamarah, 2002: 13). Menurut Sardiman, belajar merupakan perubahan tingkah laku atau penampilan, dengan serangkaian kegiatan misalnya dengan membaca, mengamati, mendengarkan, meniru dan lain sebagainya (Sardiman, 2007: 20). Prestasi belajar seringkali digunakan sebagai ukuran untuk mengetahui seberapa jauh seseorang menguasai bahan yang sudah diajaran. Prestasi yang diperoleh bukan berupa ilmu pengetahuan saja, tapi juga kecakapan atau ketrampilan. Semua bisa diperoleh dalam suatu mata pelajaran tertentu. Untuk mengetahui penguasaan atau kecakapan setiap siswa terhadap mata pelajaran itu dilaksanakan evaluasi. Dari hasil evaluasi itu dapat diketahui kemajuan siswa.

Dari beberapa penjelasan yang dikemukakan di atas, maka prestasi belajar adalah hasil yang diperoleh berupa kesan-kesan yang mengakibatkan perubahan dalam diri individu sebagai hasil dari aktivitas dalam belajar (Syaiful Bahri Djamarah, 2002: 23). Menurut Hamalik hasil belajar merujuk pada prestasi belajar, sedangkan prestasi belajar itu merupakan indikator adanya dan derajat perubahan tingkah laku siswa (Oemar Hamalik, 2003: 159). 


\section{METODE PENELITIAN}

Jenis Penelitian yang digunakan dalam penelitian ini adalah Penelitian Tindakan Kelas (PTK) yang dalam Bahasa Inggris PTK disebut Classroom Action Research (CAR). PTK sangat cocok untuk penelitian ini, karena penelitian diadakan dalam kelas dan lebih difokuskan pada masalah - masalah yang terjadi di dalam kelas atau pada proses belajar mengajar. PTK yang digunakan adalah PTK Partisipan artinya suatu penelitian dikatakan sebagai PTK partisipan apabila peneliti terlibat langsung di dalam proses penelitian sejak awal sampai dengan hasil penelitian yang berupa laporan. Dengan menggunakan model kemmis Taggart. Dalam PTK ini sejak perencanaan penelitian peneliti senantiasa terlibat, selanjutnya peneliti memantau, mencatat, dan mengumpulkan data, lalu menganalisis data serta berakhir dengan melaporkan hasil penelitiannya (Zainal Aqib, 2009: 20)

\section{A. Lokasi dan Subyek Penelitian}

\section{a. Lokasi Penelitian}

Dalam penelitian ini peneliti mengambail lokasi di Gendingan di kec. Kedungwaru kab. Tulungagung. Lokasi penelitian ini dipilih sebagai lokasi penelitian dengan pertimbangan bahwa dalam melaksanakan pembelajaran PKn di kelas IV belum pernah menerapkan pendekatan kontekstual dalam pokok bahasan sistem pemerintahan pusat yang dapat membuat siswa lebih semangat belajar sehingga membuat siswa termotivasi belajar yang nanti berdampak pada peningkatan prestasi belajarnya.

\section{b. Subyek Penelitian}

Dalam Penelitian ini yang menjadi Subjek Penelitian adalah siswa kelas IV Madrasah Ibtidaiah (MI) Al-Ma'arif Gendingan Kec. Kedungwaru Kab. Tulungagung, semester II, yang berjumlah 31 siswa dengan rincian 14 perempuan dan 17 laki-laki. Pemilihan siswa kelas IV karena pada kelas ini prestasi belajar PKn tergolong rendah, sehingga rata-rata nilai yang diperoleh siswa cenderung dibawah KKM. Hal ini yang membuat peneliti mengambil kelas ini sebagai subyek penilitian.

\section{B. Data dan Sumber data}

\section{Data}

Data yang dikumpulkan dalam penelitian ini antara lain : 1) Hasil belajar siswa baik pada tes awal maupun pada tes akhir tindakan, 2) Hasil observasi, guna mengamati kegiatan mengamati kegiatan di kelas selama kegiatan pembelajaran berlangsung dengan menggunakan lembar observasi, 3) Hasil wawancara berlangsung 
dengan subyek penelitian (siswa) untuk menggali pemahaman materi, dan 4) Hasil pencatatan lapangan selama proses pelaksanaan penelitian.

\section{Sumber Data}

Dalam penelitian ini ada 2 sumber data yaitu :

a. Sumber Data Primer, yaitu Sumber pertama dimana sebuah data dihasilkan. (Burhan Bungin, 129)

Responden dalam penelitian ini adalah siswa kelas IV semester II MI AlMa'arif Gendingan. siswa yang diambil sebagai subyek wawancara adalah siswa yang memiliki nilai tes paling rendah sebanyak 4 siswa dengan pertimbangan bahwa jika siswa yang berkemampuan rendah dapat berhasil dalam pembelajaran PKn menggunakan pendekatan kontekstual, maka siswa yang memiliki kemampuan lebih sudah tentu akan lebih berhasil, hal ini bertujuan untuk mengetahui tingkat pemahaman siswa tentang materi.

b. Sumber data sekunder yaitu sumber data kedua sesudah sumber data primer. Jenis data sekunder yang digunakan adalah :

1) Aktivitas

2) Lokasi

3) Dokumentasi

Sumber data primer dan sekunder diharapkan dapat berperan membantu mengungkap data yang diharapkan.

\section{Teknik Pengumpulam Data}

Dalam suatu penelitian selalu terjadi teknik pengumpulan data. Dalam penelitian ini yang digunakan peneliti dalam mengumpulkan data tersebut adalah sebagai beikut:

\section{a. Tes}

Dalam penelitian ini tes digunakan untuk mengukur pencapaian seseorang setelah mempelajari sesuatu.Tes tersebut diberikan kepada peserta didik guna mendapatkan data kemampuan siswa tentang materi pelajaran PKn.

Tes yang digunakan adalah soal uraian yang dilaksanakan pada saat pra tindakan maupun pada akhir tindakan, yang nantinya hasil tes ini akan di olah untuk mengetahui tingkat keberhasilan siswa dalam proses pembelajaran yang menerapkan pendekatan kontekstual pada mata pelajaran PKn.

Tes yang dilakukan pada penelitian ini adalah: 
a. Tes pada awal penelitian (pre test), dengan tujuan untuk mengetahui pemahaman siswa tentang materi yang akan di ajarkan.

b. Tes pada setiap akhir tindakan (post test), dengan tujuan untuk mengetahui peningkatan pemahaman dan prestasi belajar siswa terhadap materi yang di ajarkan dengan menerapkan pendekatan kontekstual. Kriteria penilaian dari hasil tes ini adalah sebagai berikut:

\section{Tabel 1. Kriteria Penilaian}

\begin{tabular}{ccccc}
\hline Huruf & $\begin{array}{c}\text { Angka } \\
\mathbf{0}-\mathbf{4}\end{array}$ & $\begin{array}{c}\text { Angka } \\
\mathbf{0}-\mathbf{1 0 0}\end{array}$ & $\begin{array}{c}\text { Angka } \\
\mathbf{0}-\mathbf{1 0}\end{array}$ & Predikat \\
\hline A. & 4 & $85-100$ & $8,5-10$ & Sangat baik \\
\hline B. & 3 & $70-84$ & $7,0-8,4$ & Baik \\
\hline C. & 2 & $55-69$ & $5,5-6,9$ & Cukup \\
\hline D. & 1 & $40-54$ & $4,0-5,4$ & Kurang \\
\hline E. & 0 & $0-39$ & $0,0-3,9$ & Sangat Kurang \\
\hline
\end{tabular}

Untuk menghitung hasil tes, baik pre test maupun post test pada proses pembelajaran dengan meggunakan media komik, digunakan rumus percentages correction sebagai berkut ini :

$\mathrm{S}=\frac{R}{N} X 100$

\section{Keterangan :}

S : Nilai yang dicari atau diharapkan

$\mathrm{R} \quad$ : Jumlah skor dari item atau soal yang di jawab benar

$\mathrm{N} \quad$ : Skor maksimum ideal dari tes yang bersangkutan

100 : Bilangan tetap (Ngalim Purwanto, 2004: 112).

Adapun untuk instrumen tes sebagaimana terlampir.

\section{b. Observasi}

Dalam penelitian ini observasi merupakan alat bantu yang digunakan peneliti ketika mengumpulkan data melalui pengamatan dan pencatatan secara sistematis terhadap fenomena yang diselidiki. Adapun untuk lembar observasi sebagaimana terlampir. 


\section{c. Wawancara}

Dalam penelitian ini peneliti melakukan wawancara dengan guru kelas IV dan siswa kelas IV. Bagi guru kelas IV, wawancara dilakukan untuk memperoleh data awal tentang proses pembelajaran sebelum melakukan penelitian. Bagi siswa kelas IV, wawancara dilakukan untuk menelusuri dan menggali pemahaman siswa tentang materi yang diberikan. Peneliti menggunakan wawancara terstruktur, wawancara terstruktur adalah wawancara yang pewawancaranya menetapkan sendiri masalah dan pertanyaan-pertanyaan yang akan diajukan.

\section{d. Catatan Lapangan}

Dalam penelitian ini catatan lapangan digunakan untuk melengkapi data yang tidak terekam dalam instrumen pengumpul data yang ada dari awal tindakan sampai akhir tindakan. Dengan demikian diharapkan tidak ada data penting yang terlewatkan dalam kegiatan penelitian ini.

\section{e. Dokumentasi}

Untuk lebih memperkuat hasil penelitian ini peneliti menggunakan dokumentasi berupa foto - foto pada saat siswa melakukan proses pembelajaran dengan menggunakan pendekatan kontekstual pada mata pelajaran PKn. Adapun pedoman dokumentasi sebagaimana terlampir.

\section{Teknik Analisis Data}

Dalam Penelitian Tindakan Kelas ini proses analisis data dimulai dengan menelaah seluruh data yang tersedia dari berbagai sumber, yaitu dari wawancara, observasi (pengamatan) yang sudah ditulis dalam sebuah catatan lapangan.

Beranjak dari pendapat di atas, maka penelitian ini menggunakan analisis data kualitatif model mengalir dari Miles dan Huberman yang meliputi 3 hal yaitu:
a. Reduksi data (Data Reduction)
b. Penyajian Data ( DataDisplay)
c. Menarik Kesimpulan (Conclusion Drawing) 


\section{HASIL DAN PEMBAHASAN}

A. Pembahasan terhadap kegiatan pra tindakan

Langkah awal sebelum melaksanakan pembelajaran dengan menggunakan media gambar dan model diskusi adalah melakukan tes awal (pre test), tujuannya yaitu untuk mengetahui kemampuan awal siswa tentang materi sistem pemerintahan pusat. Hasil tes awal (pre test) menunjukkan bahwa secara umum siswa belum menguasai materi sistem pemerintahan pusat karena mungkin materi ini masih pertama kali dipelajari dalam mata pelajaran PKn. Hal ini menunjukkan ketidak efektifan dalam proses pembelajaran. Bila di lihat melalui rata-rata skor tes awal, maupun dari persentase ketuntasan prestasi belajar sebagai berikut:

a. Rata-rata skor tes awal $=\underline{60,32}<\mathrm{KKM}=70,00$

b. Persentase ketuntasan $=\underline{32,25 \%}<\mathrm{KKM} \%=75 \%$

Ketidakefektifan ini disebabkan karena cara mengajar guru yang kurang menarik, akibatnya siswa menjadi kurang bersemangat dan tidak menunjukkan adanya kegairahan untuk belajar, dengan penerapan media komik ini diasumsikan dapat meningkatkan prestasi belajar siswa pada mata pelajaran PKn di kelas IV MI Al-Ma'arif Gendingan.

B. Pembahasan hasil penelitian Siklus I

Proses pembelajaran pada siklus I ini menggunakan diskusi sebagai alat penyampai/perantara materi, alasan dipilihnya model diskusi karena peneliti berharap tercapainya pembelajaran kontekstual berjalan dengan baik.

Pelaksanaan pembelajaran siklus I terbagi menjadi tiga kegiatan, yaitu kegiatan awal, kegiatan inti dan kegiatan akhir. Kegiatan awal dimaksudkan untuk mempersiapkan siswa untuk belajar, karena siswa yang siap untuk belajar akan lebih mudah memahami materi yang disampaikan.

Kegiatan awal peneliti terlebih dahulu menyampaikan tujuan pembelajaran dan mengaitkannya pada kehidupan sehari-hari siswa. Hal ini dimaksudkan agar siswa mengetahui apa yang akan dipelajari sehingga menjadi termotivasi dan terarah dalam belajarnya.

Kegiatan inti, peneliti menggunakan diskusi tentang materi baru yang akan dipelajari sehingga siswa akan lebih cepat ingat apabila mereka berusaha menyelesaiakan masalah dalam kelompok secara otomatis materi yang ingin disampaiakan peneliti sudah tersampaiakan dalam diskusi tersebut. Selain itu peneliti berharap agar siswa dapat 
menjalin kerjasama dalam kelompok sehingga dalam belajar sehari-hari mereka bisa kompak. Masalah diskusi memuat aspek-aspek penting dalam materi. Jadi, siswa akan lebih fokus dan akan memahami materi secara otomatis.

Pada kegiatan akhir dalam siklus I, peneliti melakukan penyimpulan terhadap materi bersama dengan siswa serta mencatat hal-hal yang penting. Hal ini dimaksudkan agar pemahaman siswa terhadap materi lebih tahan lama. Peneliti juga melakukan tes sebagai alat evaluasi pemahaman siswa terhadap materi, tujuannya yaitu untuk mengetahui peningkatan prestasi belajar siswa. Berdasarkan hasil post test siklus I menunjukkan ada peningkatan prestasi belajar siswa yang cukup baik dalam penggunaan media gambar. Bila di lihat melalui rata-rata skor siklus I, maupun dari persentase ketuntasan prestasi belajar sebagai berikut:

a. Rata-rata skor siklus $\mathrm{I}=\underline{64,83}<\mathrm{KKM}=70,00$

b. Persentase ketuntasan $=\underline{58 \%}<\mathrm{KKM}=75 \%$

Peningkatan prestasi belajar siswa disebabkan karena siswa ikut aktif dalam proses pembelajaran dengan menggunakan pendekatan kontekstual, walaupun ada peningkatan yang baik masih perlu dilakukan pengulangan siklus untuk mencapai kriteria yang diinginkan. Kelemahan siklus I terletak pada penyajian pendekatan kontekstual melalui model diskusi yang sedikit membuat bingung siswa dalam menjalankannya serta proses pembelajaran yang kurang berhasil karena memang tingkat kesukaran materi lumayan tinggi.

C. Pembahasan hasil penelitian Siklus II

Siklus II ini kegiatan yang dilakukan hampir sama seperti siklus II hanya saja ada sedikit perubahan pada media gambar yang kemarin di didiskusikan kini di siklus II gambar tersebut akan lebih di diskusikan lebih mendalam lagi. Selain itu peneliti juga mengasah pemahaman siswa melalui cerdas tangkas. Sehingga ada perbedaan dibandingkan dengan siklus I.

Berdasarkan hasil post test siklus II menunjukkan ada peningkatan prestasi belajar siswa yang cukup signifikan. Bila di lihat melalui rata-rata skor siklus II, maupun dari persentase ketuntasan prestasi belajar sebagai berikut:

a. Rata-rata skor siklus II $=\underline{81}>\mathrm{KKM}=70,00$

b. Persentase ketuntasan $=\underline{77,4 \%}>\mathrm{KKM}=75 \%$ 
Peningkatan prestasi belajar siswa pada siklus II ini sesuai yang diharapkan oleh peneliti karena sudah memenuhi kriteria yang telah ditenkukan jadi tidak diperlukan lagi pengulangan siklus.

D. Pembahasan hasil observasi siklus I dan siklus II

Berdasarkan hasil observasi yang dilakukan guru kelas IV (Bapak Juadi S.Pd.I) dan teman sejawat Nurina Kamila baik siklus I maupun siklus II terdapat peningkatan yang cukup signifikan. Peningkatan tersebut dapat dilihat pada tabel 4.11 berikut:

Tabel 2: Peningkatan aktivitas peneliti dan siswa siklus I dan siklus II

\begin{tabular}{ccccc}
\hline No. & \multicolumn{2}{c}{ Siklus I } & \multicolumn{2}{c}{ Siklus II } \\
\cline { 2 - 5 } & $\begin{array}{c}\text { Aktivitas } \\
\text { peneliti }\end{array}$ & $\begin{array}{c}\text { Aktivitas } \\
\text { siswa }\end{array}$ & $\begin{array}{c}\text { Aktivitas } \\
\text { peneliti }\end{array}$ & Aktivitas siswa \\
\hline 1 & $54,5 \%$ & $50 \%$ & $89,8 \%$ & $84,7 \%$ \\
\hline
\end{tabular}

Peningkatan aktivitas peneliti ini menunjukkan bahwa peneliti sudah mempersiapkan secara matang dan terencana sedangkan peningkatan aktivitas siswa menunjukkan bahwa siswa sangat antusias dalam proses pembelajaran dengan penerapan pendekatan kontekstual, sehingga siswa ada peningkatan prestasi belajar.

Tabel 3: Persentase Ketuntasan Prestasi Belajar Siswa

\begin{tabular}{ccccc}
\hline No. & Keterangan & Pre Test & $\begin{array}{c}\text { Post Test } \\
\text { Siklus I }\end{array}$ & $\begin{array}{c}\text { Post Test } \\
\text { Siklus II }\end{array}$ \\
\hline 1. & Tuntas belajar & 10 siswa & 18 siswa & 24 siswa \\
\hline 2. & Belum tuntas belajar & 21 siswa & 13 siswa & 7 siswa \\
\hline 3. & $\begin{array}{c}\text { Persentase ketuntasan } \\
\text { belajar }\end{array}$ & $32,25 \%$ & $58 \%$ & $77,74 \%$ \\
\hline
\end{tabular}

Tabel di atas dapat diketahui bahwa adanya peningkatan prestasi belajar siswa. Persentase belajar siswa mengalami peningkatan yang cukup drastis dari pre test, post test siklus I dan post test siklus II, yaitu masing-masing 32,25\%, 58\%, dan 77,74\%. Pada siklus II ketuntasan belajar siswa secara klasikal sudah tercapai sehingga tindakan bisa berhenti pada siklus ke II. 


\section{E. KESIMPULAN}

1. Penerapan pendekatan kontekstual dalam kegiatan pembelajaran PKn pada siswa kelas IV MI Al-Ma'arif Gendingan yang menggunakan salah satu komponen kontekstual yaitu masyarakat belajar (Learning Community). Siswa dikelompokkan secara heterogen dan diberikan materi diskusi untuk melatih siswa untuk bekerja secara efektif dalam kelompok, melatih siswa untuk berinteraksi dengan yang lain sehingga akan menimbulkan dampak yang positif bagi peningkatan prestasi siswa. Materi diskusi pada siklus I yaitu berupa gambar dengan tujuan supaya siswa mampu mengenal profil ketua dari lembaga pemerintah pusat. Setelah kelompok bekerjasama untuk memecahkan materi yang diberikan maka, setiap kelompok menyiapkan satu atau dua delegasi perwakilan kelompok untuk mempresentasikan hasilnya. Pada siklus I pertemuan pertama memang pendekatan ini belum sepenuhnya dikatakan berhasil terbukti hasil diskusi kelompok 90\% masih salah. Melihat fakta demikian itu peneliti menyuruh tiap anggota kelompok untuk membenahi hasil diskusi yang masih banyak salah itu. Peneliti menjelaskan bahwa mereka boleh mencari informasi melalui media elektronik, media cetak, ataupun dapat mencari informasi dari orang yang mengetahui seputar tugas kelompok tersebut. Pada pertemuan dua siklus I peneliti mengadakan post test. Dilanjutkan pada siklus II pertemuan pertama peneliti menerapkan pendekatan kontekstual komponen masyarakat belajar (learning community) lagi. Jadi tetap bekerjasama dalam kelompok dengan mengaitkan tugas kelompok pada siklus I dan dilanjutkan untuk post test siklus II. Pada pertemuan kedua peneliti mengevaluasi keberhasilan kelompok dengan mengadakan cerdas tangkas.

2. Pembelajaran dengan menggunakan pendekatan kontekstual dapat meningkatkan prestasi belajar PKn kelas IV terutama pada pokok bahasan sistem pemerintahan pusat. Berdasarkan hasil test, baik pre test, post test siklus 1 dan siklus 2 menunjukkan bahwa terjadi peningkatan prestasi belajar siswa yang cukup signifikan Hal ini terbukti dari rata rata skor pre test adalah 60,32. Rata-rata skor post test siklus I adalah 64, 83 dan pada post test siklus II adalah 81 . 
JIP:Jurnal Ilmiah PGMI

Volume 4, Nomor 1, Juni 2018
Implementasi Model Discovery.... Sigit Dwi Laksana

\section{DAFTAR PUSTAKA}

Aqib, Zainal. 2009. Penelitian Tindakan Kelas, Bandung: Yrama Widya.

Azwar, Saifuddin. 2005. Tes Prestasi, Yogyakarta: Pustaka Pelajar

Bahri Djamarah, Syaiful. 2002. Psikologi Belajar, Jakarta: Rineka CIpta

Hamalik, Oemar. 2003. Kurikulum dan Pembelajaran, Jakarta: Bumi Aksara

I Arends, Richard. 2008. Learning to Teach (terj. Belajar untuk Mengajar), Yogyakarta: Pustaka Pelajar

Mulyasa, E. 2008, Menjadi Guru Profesional. Bandung: Remaja Rosda Karya

Purwanto, Ngalim. 2004. Prinsip - Prinsip dan Teknik Evaluasi Pengajaran, Bandung: PT Remaja Rosdakarya

Purwanto. 2009. Evaluasi Hasil Belajar, Yogyakarta: Pustaka Pelajar

Sagala, Syaiful. 2012. Konsep dan Makna Pembelajaran, Bandung : Alfabeta

Sardiman. 2007. Interaksi dan Motivasi Belajar Mengajar, Jakarta: Raja Grafindo Persada

Syah, M. 2004. Psikologi Pendidikan Suatu Pendekatan Baru. Bandung: PT Remaja Rosdakarya. 